\title{
The Use of Technological Approach in Stimulate Students' Historical Thinking Skill
}

\author{
Lau Yi Yi ${ }^{1}$, Mohd Mahzan Awang ${ }^{2}$, Abdul Razaq Ahmad ${ }^{3}$, Shakila Che Dahalan ${ }^{4}$ \\ ${ }^{1234}$ Faculty of Education UKM, MALAYSIA
}

E-mail: yiyi61125@gmail.com

\begin{abstract}
Whenever students talk about their subjects in school, history is often perceived as among the most boring subject. The main reason of history has been considered as a boring subject is due to the traditional ways used by the history teachers in the class. The teacher-centered approach had made the students think that history is a vapid subject where they only need to memorize all the facts about a history event to achieve the learning outcomes. In this case, the using of technology approach in history learning process can provide students a new perspective on History Education. Technology is a useful tool that can stimulate students to generate historical thinking skills. The using of technology approach also encourage students to imagine a past event comprehensively. However, there are a lot of problems need to be solved such as the lack of facilities in schools and the skill deficiency among history teachers. Therefore, the purpose of this paper is to discuss the using of technology approach in stimulate student historical thinking skill. Besides, this paper will also discuss about the role of school and government in providing facilities and courses that train teacher with the skill needed. This is important to ensure that the technology approach can be applied effectively in history teaching and learning process.
\end{abstract}

Keywords: Technology Approach, Historical Thinking Skill, History Subject

\section{Introduction}

The era of globalization has influenced many aspects of life. Technological advancement is a major step taken by humans. Many fields have used technology to simplify their work. Technology has also brought a lot of changes in education. At the beginning of the development of information technology, computers were used only in the classroom to facilitate the teaching and learning process. Subsequently, computers have been used as tools to achieve teaching and learning objectives (Mohid et al., 2018). The use of technology in the teaching and learning process is increasingly being used by teachers in schools. This is due to the effective use of technology in achieving learning outcomes.

Students' nowadays have the opportunity to use technology tools such as computers, mobile phones and many more. It is undeniable that almost every student has the skills to use technology tools. Studies have shown that children exposed to technology can stimulate and encourage children to learn better and more effectively (Burnett, 2010). In the 21 st century, students have been trained to develop 
skills that can be used in the future such as high-level thinking skills. Teachers should always ensure that teaching and learning is carried out to meet their educational needs. Therefore, the use of technology-assisted teaching methods can assist teachers in achieving educational aspirations today.

\section{Definition}

\subsection{Technologies}

History subjects have been taught as one of the subjects of humanities after 1984. From 1992, History subjects have been the main subject of secondary school, Form One to Form Five. Since 1992, the Ministry of Education of Malaysia has viewed History from the perspective of Malaysian culture (Form Four History KBSM Syllabus, 1992). In 2002, the Form Four History Study Syllabus was reviewed to ensure current and relevant aspects were included. It has focused on preparing students for future challenges. Among the aspects that are included in the syllabus are the technology aspects. According to Lee Bih Ni (2013), the Ministry of Education Malaysia has realized the potential of technology in teaching and learning history in the future since 2002 .

Technology can be described as the application of science knowledge as the application of science knowledge in the creation of tools that enhances human capabilities. Technology is not just about tools and machines; it also involves processes and ideas. According to Derek Rowntre (1974), the concept of educational technology is an educational skill involving hardware, software and delivery methods (Abdullah, Lazim \& Zain, 2009).

According to Salleh \& Agus (2009), there are several types of technology media used in the process of teaching and learning History. Examples of materials in a technology-assisted manner are as follows:

i. Power point that can produce the content of a particular work in a computer.

ii. Videos that show the continuous improvement of the material and facts presented.

iii. Pictures that show the current situation.

\subsection{Historical Thinking Skills}

Historical Thinking skills have been applied in History subjects since elementary school. Historical Thinking Skills is an important element in History education. Through this Skill, students will be guided to think critically and analytically about historical sources and events (Curriculum Standard Documents and Four-Year History Assessment, 2019). The mastery of Historical Thinking skills enables students to see community event empathy. According to West (2006), Historical Thinking Skills is a form of cognitive process that requires students to explore complex and abstract ideas with the guidance of teachers. Thus, students can understand critically and imaginatively all aspects of human life to the present day.

The Ministry of Education Malaysia has outlined five Historical Thinking Skills that students need to master. The five constructs are as follows (KPM 2014, 2015):

i. Understanding chronological skills refers to the chronology and historical events. Students are taught the skills to understand the time span of a civilization's progress.

ii. The skill of exploring evidence involves the skill of identifying and comparing historical sources.

iii. Interpretation skills allow students to interpret an event. Students can make different interpretations and perspectives.

iv. Imagination skills allow students to engage in visual and empathic historical events.

Rationalization skills involve students in thinking and making the right decisions in solving problems.

\section{Issues in History Subject}

History subjects were incorporated into the school curriculum in the late 19th century in Malaysia. Since 2013 History has become a compulsory subject at the Malaysia Certificate of Education (SPM) level. History Subjects have also been a core subject for all elementary students in the Primary School Curriculum Standard (KSSR) since 2014. This has shown that History subjects are increasingly emphasized.

However, the subject is increasingly stressed but it is often considered boring and requires only students to memorize historical facts in order to pass the test. According to the article Philosophy of History towards Developing the Elements of Patriotism and Nationalism in Khoo Kay Kim's book The Philosophy of Culture in Education (2003) states that teaching and learning History whether at school or university is a major factor in why History is considered trivial among people. Since history was incorporated into the 
school curriculum in the late 19th century in this country (Malaysia), its teaching method has hardly changed. This subject actually did not make History a subject that could open the minds of the students because their previous concern was how to pass the exam. This situation has shown that most students do not master the skills that need to be mastered in History subjects in particular.

Khalil's (2018) study has shown that the level of mastery of Malaysian Teacher Thinking Skills is at a high level. This study shows that the level of skills of Malaysian teachers towards constructing Historical Thinking skills such as chronological skills, imagination skills and rationalization skills are at a high level. This situation shows that Malaysian teachers are capable of mastering Historical Thinking skills well. Previous studies have also shown that Malaysian teachers have a very good or very high level of Historical Thinking skills mastermind especially history teachers or teachers who have had professional training in this field (Kaviza, 2018). This situation has shown that Malaysian teachers have good levels of Historical Thinking skills but are not able to apply them in the process of teaching and learning History subjects.

\section{Research Methodology}

The method used in this study was the library study. The data collection and analysis process consists of three stages. In the first phase, researchers have sought information and research related to the use of technology-assisted methods in improving students' Historical Thinking Skills. Researchers have used internet searches such as ERIC software, Google Scholar, Research Gate and so on

In the second stage, the researcher selects information and studies that are relevant to the subject of the study, namely the use of technology-assisted methods in improving students' Historical Thinking Skills. Only relevant information and studies will be selected.

In the third stage, all information and studies identified as sources of data will be analyzed and categorized by themes. This information will provide input that is relevant to the topic of the study and will be used to further develop the idea of the issues being studied.

\section{Data Analysis}

As a result of the analysis of past studies, the strength of technology-assisted teaching methods in improving students' Historical Thinking Skills and the difficulties in implementing they have been developed.
TABLE 1 The Strength of Technology Assisted Teaching Methods

\begin{tabular}{|c|c|c|}
\hline Author & $\begin{array}{c}\text { Article/Research } \\
\text { Title }\end{array}$ & Finding \\
\hline $\begin{array}{l}\text { Shep et. al. } \\
\text { (2013) }\end{array}$ & $\begin{array}{l}\text { Exploring Digital } \\
\text { Technologies and } \\
\text { Historical Thinking } \\
\text { in undergraduate } \\
\text { learning and } \\
\text { teaching at VUW }\end{array}$ & $\begin{array}{l}\text { Improve } \\
\text { understanding } \\
\text { Develop skills in } \\
\text { exploring } \\
\text { evidence } \\
\text { Improve your } \\
\text { imagination- } \\
\text { building skills } \\
\text { Improve } \\
\text { interpreting skills }\end{array}$ \\
\hline $\begin{array}{c}\text { Tally \& } \\
\text { Glodenberg } \\
(2005)\end{array}$ & $\begin{array}{l}\text { Fostering Historical } \\
\text { Thinking with } \\
\text { Digitizes Primary } \\
\text { Sources }\end{array}$ & $\begin{array}{l}\text { Take a closer } \\
\text { look at history } \\
\text { Improve your } \\
\text { imagination- } \\
\text { building skills }\end{array}$ \\
\hline $\begin{array}{l}\text { Ramakrishnan } \\
\text { \& Abdullah } \\
\quad(2012)\end{array}$ & $\begin{array}{l}\text { The Use of History } \\
\text { Digital Source } \\
\text { among History } \\
\text { Teachers }\end{array}$ & $\begin{array}{l}\text { Improve } \\
\text { understanding } \\
\text { Improve } \\
\text { imagination skills }\end{array}$ \\
\hline $\begin{array}{l}\text { Salleh \& Agus } \\
\quad(2009)\end{array}$ & $\begin{array}{l}\text { Transformation of } \\
\text { Multimedia Based } \\
\text { History Teaching }\end{array}$ & $\begin{array}{l}\text { Improve } \\
\text { understanding }\end{array}$ \\
\hline Lee (2013) & $\begin{array}{l}\text { ICT and Teaching- } \\
\text { Learning History in } \\
\text { Schools }\end{array}$ & $\begin{array}{l}\text { Improve } \\
\text { chronological } \\
\text { understanding } \\
\text { skills Develop } \\
\text { skills in } \\
\text { exploring } \\
\text { evidence Improve } \\
\text { interpreting skills }\end{array}$ \\
\hline
\end{tabular}

TABLE 2 The Challenge of Technology Assisted Teaching

\begin{tabular}{|c|c|c|}
\hline Author & $\begin{array}{c}\text { Article/Research } \\
\text { Title }\end{array}$ & Finding \\
\hline $\begin{array}{l}\text { Shep et. al. } \\
\quad(2013)\end{array}$ & $\begin{array}{l}\text { Exploring Digital } \\
\text { Technologies and } \\
\text { Historical Thinking } \\
\text { in undergraduate } \\
\text { learning and } \\
\text { teaching at VUW }\end{array}$ & $\begin{array}{l}\text { The authenticity of } \\
\text { the material } \\
\text { Lack of skills } \\
\text { Lack of facilities }\end{array}$ \\
\hline $\begin{array}{l}\text { Tally \& } \\
\text { Glodenberg } \\
\text { (2005) }\end{array}$ & $\begin{array}{lr}\text { Fostering } & \text { Historical } \\
\text { Thinking } & \text { with } \\
\text { Digitizes } & \text { Primary } \\
\text { Sources } & \\
\end{array}$ & $\begin{array}{l}\text { Lack of teacher } \\
\text { skills }\end{array}$ \\
\hline $\begin{array}{l}\text { Ramakrishnan } \\
\text { \& Abdullah } \\
\text { (2012) }\end{array}$ & $\begin{array}{lr}\text { The Use of } & \text { History } \\
\text { Digital } & \text { Source } \\
\text { among } & \text { History } \\
\text { Teachers } & \\
\end{array}$ & $\begin{array}{l}\text { Difficulty in } \\
\text { obtaining materials } \\
\text { Lack of skills } \\
\text { Lack of facilities } \\
\end{array}$ \\
\hline $\begin{array}{c}\text { Salleh \& Agus } \\
(2009)\end{array}$ & \begin{tabular}{lr}
\multicolumn{2}{l}{ Transformation of } \\
Multimedia $\quad$ Based
\end{tabular} & $\begin{array}{l}\text { Lack of facilities } \\
\text { lack of skills }\end{array}$ \\
\hline
\end{tabular}




\begin{tabular}{|l|l|l|}
\hline & History Teaching & \\
\hline \multirow{2}{*}{ Lee (2013) } & $\begin{array}{l}\text { ICT and Teaching- } \\
\text { Learning History in } \\
\text { Schools }\end{array}$ & $\begin{array}{l}\text { Lack of material } \\
\text { The authenticity of to } \\
\text { the material }\end{array}$ \\
\hline
\end{tabular}

\section{Result \& Discussion}

\subsection{The Strength of Technology Assisted Teaching Methods}

The results show that the use of technology-assisted methods in teaching and learning processes enhances students' understanding of historical events (Shep et al. 2013; Tally \& Goldenberg 2005; Ramakrishnan \& Abdullah 2012; Salleh \& Agus 2009). According to Shep et. al (2013), the study participants stated that the use of technology-assisted methods enables them to experience the past and its circumstances. They agreed that the use of visual technology has helped them understand events more thoroughly and empathy. In addition, students will also gain a deeper understanding of historical events (Tally \& Goldenberg, 2005). The use of media such as dynamic audio, video and animation can increase students' understanding of the lessons being delivered (Salleh \& Agus, 2009). The study participants in the Tally \& Goldenberg (2005) study agreed that the use of technology-assisted methods has provided them with the opportunity to engage in deeper discussions. Students are able to give their views on a historical event as they understand the historical events in greater depth.

In addition, the analysis also showed that the five constructs in Historical Thinking Skills can be improved through the use of technology-assisted methods in the teaching and learning of History subjects. The use of technology-assisted methods can help students to better structure the historical sequence of events. They can get the information they want through internet access. They are able to find continuity between historical events and to understand their chronology (Lee, 2013).

Furthermore, the use of technology in the teaching and learning process can also enhance the skills of exploring student evidence. Students can find and access information from CD ROM / DVD ROMs and the Internet (Lee, 2013). An easy-to-access Internet property is used by students to search for relevant evidence or resources. Students can also compare the resources available. For example, students can compare archival film to modern film (Shep et al., 2013). In addition, the authenticity of the material on the internet is constantly questionable (Lee, 2013). This has provided the opportunity for students to identify the authenticity of the resource and this has also enhanced their ability to discover student evidence.
On the other hand, students' interpretation skills can also be improved. When students are given the opportunity to compare some of the resources available, they will analyze and interpret those resources (Shep et al., 2013). For example, filmmaking between filmmaking and modern film can help students compare the difference between presenting a historical event and exploring historical facts through these sources. Thus, students are able to interpret what is a myth and what is historical fact. This will further enhance the students' ability to interpret.

Next is the skill of making imagination. These skills can be enhanced because students can understand abstract concepts through visuals. The use of technology makes it easy for students to access information in many forms. The use of video enhances students 'ability to master history because it can express abstract students' imagination through the display of their images (Ramakrishnan \& Abdullah, 2012). The study of Shep et. al (2013) shows that students are able to analyze a source more carefully as students are given the opportunity to view the source in the form of a picture or video.

Finally, skills make rationalization. The use of technology enables students to have group discussions. They have been given the opportunity to seek information and analyze new problems (Shep et al., 2013). The forum provided the opportunity for the students to think and make the right decisions in the discussion. Therefore, the use of technology-assisted methods in the process of teaching and learning historical subjects can also enhance students' rationale skills.

In a nutshell, the use of technology-assisted methods in the process of teaching and learning historical subjects not only enhances students' understanding of historical events. The use of technology-assisted methods also provides opportunities for students to discover, to analyze and to interpret information obtained to enhance students' Historical Thinking Skills.

\subsection{The Challenge of Technology Assisted Teaching}

The use of technological methods in improving Historical Thinking Skills has faced several problems. This issue can be discussed in four aspects. These are the material aspects, the facilities aspect, the teacher aspect and the student aspect.

From a material standpoint, the main challenge faced is the scarcity of digital resources. Materials that are capable of applying Historical Thinking Skills are limited. This shortage in Malaysia is due to the lack of sharing among schools or other institutions in the search for 
materials. Although there are, it is a limited partnership aspect to partnerships related to the construction of examination questions or bank questions (Lee, 2013). According to the study of Ramakrishnan \& Abdullah (2012), one of the challenges in implementing technology-assisted methods is that the process of acquiring digital resources takes a long time. In addition, the authenticity of the material on the Internet is constantly questioned (Lee, 2013). Lack of student skills in analyzing the authenticity of resources has further complicated the process of implementing this method. Not all information obtained from search engines is authentic and reliable (Shep et al., 2013). Most students are not able to make an accurate analysis of the material obtained. They can easily believe in some unauthorized material. Therefore, the validity of the materials, the disadvantages and the difficulties in obtaining the materials have been a challenge in implementing technology-assisted methods to enhance students' Historical Thinking Skills.

The next aspect is the convenience aspect. Schoolrelated facilities are also a challenge in implementing this method (Ramakrishnan \& Abdullah, 2012). According to Salleh \& Agus (2009), the classroom situation should be complemented by its ability to deliver appropriate movies and sound. However, this facility is not available in every classroom or school. Furthermore, not all students are able to access the internet especially when they are in their own home (Shep et al., 2013). This method should allow students to study anywhere and anytime. But the lack of necessary facilities made this process difficult. Most rural schools that do not have direct electricity cannot use this method. In a state of scarcity of facilities, teachers have not been able to implement technology-assisted methods in improving students' Historical Thinking Skills.

The last aspect is the teacher aspect. Teachers lack the skills and experience in implementing this method (Ramakrishnan \& Abdullah, 2012). This can cause teachers to be unable to effectively teach and teach. The role of teachers has been facilitated by the facilitators in the implementation of this method (Shep et al., 2013). Teachers are responsible for guiding students in the process of finding information and analyzing the information obtained. According to Tally \& Goldenberg (2005), a lack of teacher skills may cause students to think that this process is a "routine" process rather than a process that involves thinking like a historian. In addition, according to Salleh \& Agus (2009), teachers' preparation in implementing this method is also very important. A history teacher who is unable to provide effective teaching and learning processes will face many problems such as the preparation of an unsuitable topic. Therefore, teachers' readiness and lack of skills have also been a problem in implementing this method.

\section{Research Implications}

The use of technology-assisted methods in improving students' Historical Thinking Skills is possible. However, some challenges need to be overcome in order to be successful.

To overcome the challenges that teachers face, teachers should strive to equip themselves so that they are not "outdated". Basic skills in the use of technology tools should be provided for every teacher. Teachers should also increase their readings in order to improve their knowledge of how to implement this method. Teachers should be aware of the importance of their role as facilitators in guiding students in the teaching and learning process so that teachercentered teaching methods can be transformed into studentcentered teaching methods. This not only enhances students 'understanding of an event, but also enhances their students' Historical Thinking Skills. Therefore, teachers need to adapt to the 21 st century teaching and learning methods to ensure students' critical and creative thinking can be improved.

In addition, the school should endeavor to equip the school with the necessary facilities. Schools should focus on the technology aspects of the teaching and learning process. Students should always be given the opportunity to venture into this field. Schools can also hold workshops or courses to enhance teachers' skills in using this method. Furthermore, the community should also provide support for the school to implement this method. Parents should guide and nurture their children to learn through technology at home. Parents should play their part in supervising their children in the home learning process.

Finally, the government should also provide the necessary infrastructure and facilities. The government should take this aspect seriously and strive to provide all the necessary facilities including the interior. The situation helps students from poor or disadvantaged families to learn using technology. This experience is particularly useful for them as they pursue higher education. The Malaysian Ministry of Education should also provide courses or workshops to equip teachers with the knowledge and skills required to implement this method. The Ministry of Education can also encourage the sharing of materials between schools so that the existing materials can be collected and used by all teachers.

\section{Conclusion}

In conclusion, the use of technology-assisted methods should be developed in education. This method should be used in the process of teaching and learning history subjects so that students can master the History Thinking Skills well. 
Mastery of these skills is in line with 21 st century learning that emphasizes students' high-level thinking skills. To achieve this, the cooperation and support of the various parties is crucial to the successful implementation of this method and thus enhancing the students' Historical Thinking Skills.

\section{References}

[1] Abdullah, N., Lazim, N. R. J. M. \& Zain, R. A. 2009. Teknologi dalam Pengajaran dan Pembelajaran. Selangor: Penerbitan Multimedia Sdn. Bhd.

[2] Bahagian Pembangunan Kurikulum. 2014. Dokumen Standard dan Pentaksiran Mata Pelajaran Sejarah Tahun Enam. Putrajaya: Kementerian Pendidikan Malaysia.

[3] Bahagian Pembangunan Kurikulum. 2019. Dokumen Standard dan Pentaksiran Mata Pelajaran Sejarah Tahun Empat. Putrajaya: Kementerian Pendidikan Malaysia.

[4] Bih Ni, L. 2013. Ict Dan Pengajaran-pembelajaran Di Sekolah.

[5] Burnett, C. 2010. Technology and Literacy in Early Childhood Educational Settings: A Review of Research. Journal of Early Childhood Literacy, 10(3), 247-270.

[6] Jabar, B. 2006. Pelaksanaan Kemahiran Pemikiran Sejarah Dalam Pengajaran Guru-Guru Sejarah: Satu Kajian Kes Di Daerah Hilir Perak.

[7] Kaviza, M. 2018. Pengalaman Mengajar atau Latihan Profesional Guru dalam Mempengaruhi Penerapan Kemahiran Pemikiran Sejarah dalam Mata Pelajaran Sejarah di Sekolah Menengah. EDUCATUM Journal of Social Sciences (EJoSS), 4(1), 40-47.

[8] Khalil, M.Y. 2018. Tahap Pengetahuan Guru Sejarah Sekolah Rendah dalam Kemahiran Pemikiran Sejarah (KPS). National Innovation and Invention Competition Through Exhibition (iCompEx'18).

[9] Khoo, K.K. . 2003. Falsafah Sejarah Ke Arah Perkembangan Patriotisme Dan Kenegaraan. In Abd. Rahim. Abd. Rashid (Eds.) Falsafah Budaya dalam Pendidikan (pp. 31-40). Kuala Lumpur: Penerbit Universiti Malaya

[10] Mohid, S. Z. et.al. 2018. Teknologi Multimedia Dalam Pendidikan Abad 21. In 5th International Research Management \& Innovation Conference, Putrajaya, Malaysia.

[11] Ramakrishnan, R., \& Abdullah, S. H. 2012. Penggunaan Sumber Digital Sejarah dalam Kalangan Guru Sejarah. In Seminar Kebangsaan Majlis Dekan Pendidikan IPTA.

[12] Salleh, M. J., \& Agus, A. 2009. Transformasi pengajaran Sejarah berasaskan multimedia. Penerbitan
Bersama: Fakulti Pendidikan, Universiti Kebangsaan Malaysia, Bangi \& FKIP, Universitas Riau, Pekan Baru Indonesia.

[13] Shep, S. J., Sheehan, M., \& McKinley, D. 2013. Exploring Digital Technologies and Historical Thinking in undergraduate learning and teaching at VUW.

[14] Tally, B., \& Goldenberg, L. B. 2005. Fostering historical thinking with digitized primary sources. Journal of Research on Technology in Education, 38(1), 1-21. 